\title{
The French Mainstream Model to Deal with Diversity
}

\author{
Danielle Zay*
}

\author{
Universtiy of Charles de Gaulle Lille 3, France
}

\begin{abstract}
France has been a country of centralist traditions since the French Ancien Régime of the monarchy, and has been universalist since the Declaration of the Rights of Man during the French Revolution, first applied to the schools of the 3rd Republic at the end of the $19^{\text {th }}$ century. It privileges individual rights as the basis of the State and considers nationality along the lines of integration and assimilation and citizenship in line with homogeneousness [1,2].

Other European countries privilege birth in a community with regards to their citizenship within the State, but this means that while differences are respected, there is a risk that the differences take precedence over what is common to everyone in a nation.

The paper will compare strength and weaknesses of the French mainstream model with those of other European countries.

For instance, an American inquiry shows that while half of British Muslims consider there is a "natural conflict between practicing Islam and living in modern society," $72 \%$ of French Muslims see none, a proportion identical to that recorded for French society overall [3, 4]. Is it a positive effect of an educational policy founded on secularisation?
\end{abstract}

The weakness of French educational policies is to take insufficient account of all the many differences with respect to knowledge, whatever their socio-cultural, psychological or physical origins.

Nevertheless, the French model is changing thanks to the European Union. It will be explained why and how.

Keywords: Alternative solutions, assimilation-integration, inclusion, centralism-decentralisation, communities, democratic education, liberalism, secularisation.

\section{INTRODUCTION: KEY ISSUES AND METHODOLOOGY}

France has a different conception and policy than other foreign countries in regard to minorities whatever they be. In the present research report for which I was responsible [5], we insist on the problem to take into account individual differences in the French Republican school tradition. In this paper for a European review, I choose the example of Muslim community because France is the European country with the largest immigrant population from Muslim countries: 5 million, one third of European Muslims [3]. This fact is worthwhile to be deepened for two reasons:

- it raises the same problems as in other Western societies,

- the results of the well-known American Pew Research Centre survey about Muslim populations in Britain, France, Germany and Spain published in 2006 show a better socio-cultural inclusion of Muslims in France than in other countries [3, 4].

As it appears in the publications by the Council of Europe we quoted in our report, France has the same target to educating citizens-to-be for democracy, but the model that inspires it is different.

*Address correspondence to this author at 8 Boulevard Pereire, 75017 Paris, France; Tel: +33 (0) 1422768 98; E-mail: danielle.zay@daniellezay.fr
As it appears in the publications by the Council of Europe we quoted in our report, France has the same target to educating citizens-to-be for democracy, but the model that inspires it is different $[1,2,5]$.

The few pages allocated to each paper do not make me able to say but a few words about our methodology. It is based upon:

- Review of ongoing comparative research on education and social inclusion measures, 1988 onwards.

- An inventory of relevant scientific publications,

- Case studies led by specialists and which have generated scientific publications.

The selection of references is inspired by "The concept of inclusive education referred to that structure and contents of mainstream education that offers full opportunities to all pupils, including the pupils with special needs, restrictions and challenges. The model is opposed to special education that is placed, structurally and substantially, outside mainstream education, e.g. in special schools for pupils with very challenging behaviour" [6], inspired by the UNESCO $[7,8]$.

The corpus consists of research and inquiries results already published in books or referred reviews, or disseminated in reports through websites, and of specific case studies elaborated in relation to the project research themes [9-12]. It also includes indicators and statistics 
collected in the ten countries participating in the project and in others.

The following documentation has been gathered together on measures supporting:

- $\quad$ Schools with high drop-out rates and with high scores on other possible indicators of social exclusion,

- In socio-economically deprived areas,

- With large populations of pupils from immigrant backgrounds,

- Teachers working in such schools,

- Schools and teachers dealing with the problem of harassment and bullying,

- Pupils likely to become early school leavers,

- Pupils with a physical or mental handicap,

And support measures to facilitate the educational success of pupils from minority backgrounds: ethnic, linguistic, religious, regional, etc.

I will introduce successively:

- The French mainstream model - the republican school - and its evolution,

- $\quad$ French and other foreign policies results in relation to social inclusion,

- $\quad$ Strengths and weaknesses of the French mainstream model,

- Conclusion: Towards alternative solutions to centralism and "communitarianism".

\section{THE FRENCH MAINSTREAM MODEL: THE REPUBLICAN SCHOOL AND ITS EVOLUTION}

The demand by minorities or specific social bodies for the right to different treatment compared to other citizens has been a bone of contention in France ever since the French Revolution in 1789 and the universal declaration of the rights of man. As all people, by their very nature, are free and equal humans, the new political representatives of France, in the name of this value of universalism, recognised the same rights for all individuals, independent of their community of birth and their social, ethnic or religious background, the tiers état, the lower social class, as well as Jews and slaves in the French West Indies, and at the same time abolished anything that might link these same individuals to a specific social entity. For instance, the corporations that governed professions under the Ancien Regime (previous monarchical system) were abolished.

"Social integration developed in France around the idea of individual citizenship. It is as if political society was influenced by Rousseau's general ideology, which was hostile to intermediary bodies. However, he acted according to a regulatory principle which was conveyed by institutions and social practices, not by a description of the reality " [13].

It is true that state schools strictly observe this regulatory principle.

"Neither regional specificities nor national origins nor the religious beliefs of the pupils were taken into account. They were all treated uniformly and equally as future citizens and all received the same teaching (...). By treating all children in the same way, without taking their origins or social characteristics into account, the republican school formed citizens who shared the same language and the same historical and cultural references" [13].

Nonetheless, "the institutions did not manage the 'citizen' but real individuals. The universal principles were inevitably adapted to specific cases." [13].

The same applies to schools today as those of yesterday: "Universal principles are asserted but, given the massification of education, how can we avoid adapting them to specific populations as we have always done in the past ?" [13].

During the 3rd Republic, claims by regional minorities were bitterly fought, embodying resistance to a republican citizenship, which was developed as a value of a universality assimilated with uniformity. All regional minorities had to give up their mother tongue, not a language, a patois, to become French. No such sacrifice is expected of Muslims nowadays. Pupils can choose their regional language or Arab as an option at school.

It is the same with the creation of ZEPs (Zones d'éducation prioritaire : Education Priority Zones, EAZ: Education Action Zones in the UK) along the lines of positive discrimination, republican equality was officially refuted in 1981 in its role as the only means of ensuring "equal opportunities" and compensating for existing social inequalities [5].

Intercultural education, which was inconceivable at the time of the 3rd Republic when school stopped at the end of primary level for all except a minority of privileged children, has become a requirement, both with the target of more than $2 / 3$ of all children reaching the level of baccalauréat, secondary school leaving examination certificate, and the multiplicity of different cultures [5].

But, "we have to keep the universal republican" principle of a school that transmits the founding idea that political legitimacy and the source of social ties rely on "the free and equal community of citizens" as, for the author, this is the closest formula to democratic values [14]. It has fewer perverse effects than the idea of "communitarianism", but it must also, inevitably, be continually improved.

"The French education system considers that any differentiation based on national, ethnic or religious specificities will be perceived and treated as a form of stigmatisation. This is demonstrated, for example, by the reactions to the introduction of languages and cultures of origin classes (LCO: Langues et Cultures d'Origine) introduced in 1975. The measure was adopted following European directives. Teachers from the countries 'of origin', in other words, the origins of the parents, provide specific education to specific pupils within the confines of the normal school programme and during normal school teaching hours. It is an exception to the general rule of universality-unity of the education system and is ill-accepted by everyone (pupils, pupils' parents and French teachers), insofar as it differs from the logic of the standard French policy and the teachings assimilated by all the social players. As the writer 
Cavanna, son of an Italian immigrant, said "I tell you, your mother tongue is the language of school" [13].

This principle is claimed by other people in Muslim societies, like Amin Maalouf [15, 16], a Lebanese speaking Arab and French, who chose to live and publish in France (he got the Goncourt award). He thinks that it is a policy based on quotas to respect all minorities that caused the clash between them in Lebanon.

What effects does the French school system have?

\section{FRENCH AND OTHER FOREIGN POLICIES RESULTS}

\subsection{Impact of the French Education System on Young People from Immigrant Backgrounds}

For Dominique Schnapper, and for the researchers she cites, this system has its advantages. "All the sociological studies show that foreign children, when they have been in nursery school in France, have the same tastes, the same knowledge and the same behaviour as French children of the same social level. If we take their social relations into account, their school results are even slightly better than those of French children with the same social level. However, at the same time, indirectly and surreptitiously, the school system guides the pupils differently, taking their capacities into account as they are judged by the teachers." [13].

Françoise Lorcerie believes that there is indeed discrimination, as much when they're looking for a job, as in the way the school system functions [17].

However, like other researchers, she also highlights the diversity of populations from North African backgrounds and the fact that ethnicity is not only a factor of failure but also of success at school [18]. Reflecting on the study by the DEP, the ministry assessment department, regarding the schooling of young people from immigrant backgrounds [19] and the study by the MGIS (Mission générale d'insertion sociale: General social integration mission), she noted that, whatever the obstacles that constitute the negative representation of immigration, and "as the social position of the family and the educational level of the parents are by far the key explanatory factors regarding schooling," young people between 20-29 years old from Algerian backgrounds often study longer. There is an ethnicity effect, which is explained by a "mobilisation which is nurtured by the feelings of pupils and their families. Their ambition reflects their resistance to "the collective experience of stigmatisation and relegation, as much in their neighbourhoods as in the schools or socially devalued classes."

A study on schooling conducted by the DEP in 2002, with a population of 16,701 pupils entering the first year of secondary education in 1995 [20] qualifies this assertion. Only $27 \%$ of children from immigrant backgrounds manage to reach the level of the general baccalauréat, against $40 \%$ of pupils with native French parents and $48 \%$ from mixed background families. But, in a comparable social and family situation, their results are not worse. On the contrary, statistically more of them prepare the baccalauréat. In addition, "children from immigrant backgrounds present less risk of leaving the school system early than other pupils, mainly because of their strong ambitions."
Another recent report on young people of North African origin who have succeeded socially [21] confirms that they themselves put their success down to their ambition, with the same refusal of communitarianism as the French overall.

This population is defined by Djida Tazdaïd, former Member of the European Parliament (Green Party), and founder of the Movement of Secular Muslims in France, launched in May 2003, as "a generation that has come of political age" and that "wants to turn a culture of failure into a culture of ambition. It may look like lobbying but there is a determination to fit into a republican rather than a communitarian space." Amirouche Laïdi, founder of the Averroès club in 1997, said: "We are not interested in communitarianism. What we have in common with the other members is discrimination, not ethnic origin." The aim of Averroès is to feed diversity to the media in order to put a stop to "the clichés and stereotypes."

\subsection{French and Other Foreign Policies Results on Muslim People}

The study led by the Pew Research Center, one of the most highly reputed public opinion institutes in the United States [4], confirmed the French positions.

European Muslims have the same problems of unemployment within their community (83\% in France, $78 \%$ in the UK) and are concerned about Islamic extremism. In terms of integration, however, the French differ. While half of British Muslims consider there is a "natural conflict between practicing Islam and living in modern society," $72 \%$ of French Muslims see none, a proportion identical to that recorded for French society overall. French Muslims are also, like the Spanish, the ones who feel the least hostility to practicing Muslims, and 39\% believe that most Europeans are hostile to Muslims against 52\% in Germany. Asked what defines them the most, their nationality or their religion, $81 \%$ of British Muslims opt for the latter, while only $46 \%$ of French Muslims said religion, against an almost equal proportion, $42 \%$, for nationality. These results are very different to those of the French population as a whole in which $83 \%$ identify first of all with their nationality, but the figures are close to those found in the US, where $48 \%$ of the population define themselves firstly as Americans and $42 \%$ as Christians. Finally, the perspective of French Muslims on other religions is much more positive. $91 \%$ of French Muslims have a favourable opinion of Christians and $71 \%$ have a good opinion of Jews, which makes them an exception: only $32 \%$ of British Muslims and $38 \%$ of German Muslims have a good opinion of Jews.

These results could be interpreted as the positive effects of an educational policy founded on secularisation in France, which considers religion as a private affair that should not interfere with school, unlike educational policies that privilege the milieu of origin. It indicates an intercultural education, concerned with making differences a positive factor in the construction of the citizen's identity [22].

For an American citizen as Christian Joppke, Professor of Political Science at the American University of Paris, French laïcité (secularity) is a variant of American liberalism and France is "America's sister republic" [3]. 
"One is usually impressed by the estimated figure of 5 millions Muslims residing in France, which makes them by far the largest Muslim minority in Europe. One third of the European total. But their overwhelming majority is Muslim only in ethnic, not in religious terms. In France, 'Islam' is an issue only a minority within a minority.

On the opposite side, one must realize that the republicanism that has formed the reception of Islam and of Muslims in France is a variant of liberalism. In fact, French republicanism, strikingly resembles 'political liberalism' [23]. Both share an iron-clad distinction between public and private, and especially a demanding abstraction from private concerns and idioms in the public sphere. As Rawls reminds us in the opening pages of his Political Liberalism, the historical origin of liberalism is in privatization of religion, which in France is referred to a laïcité. While in the private sphere, one may be a religious believer, in the public sphere one becomes a citizen engaged in 'public reasoning' [23]: abstracted from one's private demons. One never uses religions or other 'comprehensive doctrines' there, but only a political (read republican) language which may be understood and agreed upon by those who are otherwise divided by religion or ideology" [3].

\section{STRENGHS AND WEAKNESSES OF THE FRENCH MAINSTREAM MODEL}

As we saw, the republican school secular principle is not responsible in itself for the problems affecting pupils from immigrant background, such as Muslims, at school. On the contrary, it allows a socio-cultural inclusion better than other policies. Therefore the school failure is to analyse from another standpoint.

\subsection{The Incapacity of the French School System to Take Differences into Consideration}

Young people from immigrant background feel to suffer from discrimination at school as in the society and some tend to drop in or out. With respect to disaffection like any other problem posed by pupils who do not fit into the general norm, i.e. young people from disadvantaged neighbourhoods or from ethnic or religious minorities, recourse to violence, handicap, etc., the same weakness comes up time and again : the inability of the school system to take differences into account and the tendency to multiply the number of targeted initiatives rather than to try to resolve difficulties at school when they arise within the normal school programme.

We are within the definition of inclusion by UNESCO (United Nations Educational, Scientific and Cultural Organisation): "Inclusion is not about : reforms of special education alone, but reform of both the formal and nonformal education system; responding only to diversity, but also improving the quality of education for all learners; special schools but perhaps additional support to students within the regular school system; meeting the needs of children with disabilities only; meeting one child's needs at the expense of another child." (8). According to UNESCO's Guidelines for inclusion it is seen as: "a process of addressing and responding to the diversity of needs of all learners through increasing participation in learning, cultures and communities, and reducing exclusion within and from education $[\ldots]$ Inclusion is concerned with providing appropriate responses to the broad spectrum of learning needs in formal and non-formal educational settings. Rather than being a marginal issue on how some learners can be integrated in mainstream education, inclusive education is an approach that looks into how to transform education systems and other learning environments in order to respond to the diversity of learners. It aims towards enabling teachers and learners both to feel comfortable with diversity and to see it as a challenge and enrichment of the learning environment, rather than a problem." [7].

The issues are raised by the great deal of supporting measures required to make the process of integration successful: modifying the culture of teachers and other educational personnel, modifying the premises, teacher training, human resources, teaching materials, etc.). "The main challenge with integration is that 'mainstreaming' had not been accompanied by changes in the organisation of the ordinary school, its curriculum and teaching and learning strategies. This lack of organisational change has proved to be one of the major barriers to the implementation of inclusive education policies." [7].

Thus, the weakness of French educational policies does not lie in the principle of the republican school, which recognises equal rights for all its citizens, whatever their origins, but in the abuses that led it to take insufficient account of all the many differences with respect to knowledge, whatever their socio-cultural, psychological or physical origins. We also look at both the conflicts that lead to the need to adapt to the socio-cultural realities of today the original French school model, and the obstacles to an intercultural education that exist in representations and practices more than in the law, or how to meet the 'challenges' posed by ethnicity [24].

All pupils suffer from an often restrictive universalist vision which is accompanied by a tendency towards homogenisation linked to the French school model. All the issues raised in the French national report, bring us back to the study of support strategies for teachers and schools in order to respond to the problems posed by pupils who do not fit in with the academic norms corresponding to an " average pupil " whether because of disaffection from school, a socioeconomically disadvantaged situation, violent behaviour, differences arising from membership to an ethnic, religious or linguistic minority, or a physical, intellectual or cultural handicap.

The result of this failure in the system as a whole is that pupils who come back to the fold after joining a "rebound programme" tend to drop out again despite being remotivated to continue studying and returning to a secondary school class, considered by researchers as the key success factor. At various moments in the French report, we noted that the different teaching methods observed in specific programmes for pupils in difficulty could be a welcome addition to the general curriculum.

France is currently going through ambitious reforms and a reversal of what was previously set up ten years earlier. There has been a steady stream of new decrees since the new government came into power and this makes it virtually impossible to assess the impact at present. No research results are available to date. In addition, our study focuses on 
the measures taken with respect to social integration and support strategies for schools and teachers rather than the French education system as a whole.

However, the changes introduced in the education system have led to a climate of crisis that does not encourage teachers and other staff concerned to focus on pupils' problems - and even less on problem pupils - and, in addition, some of the new ministerial regulations affect the sector of young people in difficulty directly.

\subsection{The Lack of Memory in the system and of Continuity in Policies}

France, a Latin country, has inherited the Roman tradition of written legislation, which it tends to overuse. With respect to secular matters, the law may clarify a confusing situation and impose rules that reduce conflict. However, the law cannot be a substitute for adaptation and regulations concerning everyday practices. Lawmakers could draw lessons from these. Information feedback to the ministry, which continues to centralise decisions, is poorly managed. Not enough time is given to assessing the effects of the reforms introduced before new ones are created. Due to lack of evaluation and information feedback to the deciders, there tends to be an accumulation of specific measures and a lack of resources to support those, which could provide the most effective solutions. The shortcomings in the national education system combine with overlapping problems in other areas.

Thus, the ANRU (Agence nationale pour la rénovation urbaine: National agency for social renovation) assessment committee produced a report denouncing the inadequacy of the financial resources for the urban renovation plan, which the nonetheless considerable contributions from the local authorities cannot make up [25].

\subsection{Differentiating the Principles and their Application. The influence of the European Union}

More than centralisation and universalism, it appears that it is mainly the injustice of exclusion for whatever reason (community roots, poverty, unemployment and stigmatisation) that leads social groups to violence. It seems that we are too quick to consider phenomena that could be interpreted otherwise as arising from a problem of "communitarianism" or "community-ism." In the middle of the $1980 \mathrm{~s}$, for example, certain demonstrations against racism and in favour of equality were called the "March of Beurs" (immigrants of North African origin living in France), probably reflecting an expression of political aspirations.

According to Olivier Noël [26, 27], confidence in the republican integration model and the banning of ethnic statistics delayed the development of greater general awareness, but from 1998, under the influence of the EU (European Union), there was greater recognition of discrimination at national level.

Following the summit meeting in Florence, held on 21 October 1995, and the joint declaration in favour of the fight against discrimination, research studies were funded by the social action funds for immigrant workers and their families
(FAS: Fonds d'action sociale pour les travailleurs immigrés et leur famille) and the European Union.

This sociological recognition was completed by an adaptation of the juridical approach following France's ratification of the Treaty of Amsterdam in 1997, in which article 13 stipulated that the European Council is authorised to -take all measures necessary to combat all discrimination based on sex, race or ethnic origin, religion, convictions, disability, age or sexual orientation. Official recognition of the existence of discriminatory practices was expressed at the highest level of the State. In parallel, the territorialisation of the policy in the fight against discrimination developed through the CODAC (Commissions d'Accès à la Citoyenneté/Commissions of Access to Citizenship) and municipal contracts. In September 2004, the CODAC became known as the COPEC (Commission pour la promotion de l'égalité des chances"/Commission for the promotion of equal opportunities), whose aim was to federate departmental initiatives in the fight against discrimination. A decree published on 30 December 2004 created the HALDE (Haute Autorité de Lutte contre les Discriminations et pour l"Egalité/High Authority in the Fight against Discrimination and for Equality). Finally, the decree of 31 March 2006 for equal opportunities was introduced, presented as an ambitious and global response, and adequate to deal with the challenges raised by the urban and social riots of November 2005. It transformed the FASILD, whose mission was the fight against discrimination, into the ANCSEC (Agence nationale de cohésion sociale et d"égalité des chances: National agency for social cohesion and equal opportunities).

The principle is that : French citizens are all equal from their individual rights and all different from their individual history. The latter includes both what they receive from birth and what they live by themselves in other social groups than their family. As said, Amin Maalouf [15], why would we give more importance to the birth than to all the individual choices made by a person all along his/her life ? To him, it is no more important to be born Lebanon than to choose French nationality.

\section{CONCLUSION}

\section{Alternative Solutions in France as "America's Sister Republic"}

France is a European country and cannot be ruled aloof from its international context. French education is likely to be improved by analyzing it with respect both to its national and international context. The comparative point of view expressed by the American professor Christian Joppke [3] could be a main thread for France and other European countries.

As we saw, he considers French republican school principle of laïcité (secularity) as a variant of American "political liberalism" and France as "America's sister republic".

Comparing British and French policies, he observes: "the fact that Britain is now routinely forced to deal with rather extremist claims, at considerable public expense, suggests that this cannot be the best of all religious governance worlds. Moreover, British Muslims, though pampered by a 
unique accommodating government rank among the most dissatisfied and alienated Muslim minorities of Europe, which casts a long shadow over Britain's liberal multiculturalism (...). By contrast, France has nothing of this. This is despite the fact that this country is usually attacked for its heavy line on the headscarf, deemed only to alienate her Muslims and to fuel further Islamic extremism. In reality, France is the only country in Europe to confront its Muslim minority with an attitude, and one that has paid off. This is because it has not been an attitude of exclusion or racism, as some have argued, but of setting clear and equal terms of integration. Muslims have understood and accepted these terms." [3].

But school failure remains and pupils continue to drop out. The pessimistic conclusions that we have just drawn may lead us to question the solutions needed by an education system that appears to be poorly managed. Nonetheless, alternatives solutions have always existed, based on initiatives introduced by social players, which correspond to those put forward by our present research with respect to each topic. When policies are in place to support them, they develop and spread throughout the system, for those who wish to innovate have more resources to do so and are helped by the school and social climate. In periods of recession, they live on in a few more small pockets than before.

In our French team report, a whole chapter including four case studies by specialists is devoted to alternative solutions inside the mainstream model and our conclusion enlarges them [9-12].

One of my papers at the ECER 09 [28] and a following publication [29] develop them.

Here, I can only introduce some of them.

One factor, which has changed over the last twenty years, is that the effects of decentralisation have introduced opposition forces that challenge the central decisions. Even if the State changes its policy and its emanations as represented by the local education authorities in the regions, even if the regional and local communities complain about having far less power than their colleagues abroad and the transfer of State credits is far less than the money needed to manage all the work it is expected to do, they can nonetheless develop their own, more continuous policies in the regions, the departments and the urban areas [30]. These allow local schools to have more initiatives with other social actors.

A key factor for pupils' success is putting school programmes and specific initiatives and learning about otherness at the centre of our proposals as a programmearticulating concept. It involves reassessing support strategies for schools and teachers with respect to their pupils, not only with regard to the learning content and the tools used, i.e. school textbooks, but also as a community promoting the development of identity as a citizen by membership to multiple communities that are open to one another, their families, peers, school and the city.

The case study by Yves Reuter on the Freinet school in our report, illustrates the concept of a school which has overcome its locally-based operating autonomy to focus not just on the programmes or on the child, but on the learning input, the link between the pupil, the content and the resources, and their appropriation in a socio-economically disadvantaged environment.

"The school as a community was set up - and is constantly re-established" by various mechanisms and processes which different groups, pupils and teachers take part in, in communities that may be extended to others. It is "set up as a relatively autonomous micro-society," whose members (teachers and pupils), mutually considered as "school citizens," draw up specific rules and regulations. Learning is taken even more seriously in that the school is open to researchers who rigorously assess the working methods in place and their results $[12,31]$.

Thus, the dilemma between "communitarianism" and secularity does not need to exist if we consider that all democratic societies must respect both the beliefs and the lifestyle choices of its members, and the fact that they themselves respect the same laws as the others.

However, this also implies that there should be no injustice in either laws or social practices, at school and elsewhere, with regard to minority groups or dominated social categories. Women are not in the minority in terms of number and pupils from immigrant backgrounds may not be in the minority in certain classes. They may both be - or feel they are - discriminated against by teaching practice and/or schoolmates, and at the same time violently oppress other minority schoolmates. This is the well-known process by which oppression continues because the oppressed are also oppressors, as illustrated by Augusto Boal [32], referring to a type of theatre that involves the spectators in order to raise their awareness.

The position of a researcher like Dominique Schnapper [14] appears to be compatible with political choices other than those of a school founded on French republican universalism.

As I said, this implies retaining the principle of a school that transmits the basic idea that political legitimacy and the source of social ties are built on "the community of free and equal citizens," as this is the formula that best conforms to democratic values. It has fewer pernicious effects than the notion of "communitarianism," but it must also continually amend the notions regarding respect for the distinctive characteristics of each individual.

In every case, we believe that the importance of symbolic and social representations is neglected and, while they cannot replace a policy of necessarily costly compensation of inequality, their advantage is that they can be applied by everyone without any other effort than some personal soulsearching. Education could easily provide this at every level.

\section{ACKNOWLEDGEMENTS}

To Cécile Carra, professor, IUFM Nord/Pas-de-Calais University of Artois, Head of the Research Centre RECIFES.

Michèle Guigue, professor, Maryan Lemoine, PhD, Graciela Padoani David, PhD, and Bernadette Tillard, senior lecturer, PROFEOR-CIREL research team, Educational Sciences, University of Charles de Gaulle Lille 3; Yves Reuter, professor, THEODILE-CIREL research team, 
Educational Sciences, University of Charles de Gaulle Lille 3; For their contribution to the French report and to PRISME Association and his president Jean Roucou for supporting and managing the project in France.

\section{CONFLICT OF INTEREST}

None declared

\section{TERMS AND TERMINOLOGY/ LIST OF ABBRE- VIATIONS}

Agrégation : National high level competitive examination for recruiting teachers in secondary school. The highest qualification available for teachers at secondary level. Most successful students prepare it in a "Grande Ecole", the "Ecole Normale Supérieure", that is to say a higher education institution with a competitive entrance examination, unlike universities which are obliged to accept all students who have passed the baccalauréat at the end of secondary school (bacheliers).

Ancien Régime: French monarchical system before the Revolution of 1789.

ANCSEC: Agence nationale de cohésion sociale et d"égalité des chances: National agency for social cohesion and equal opportunities.

ANRU : Agence nationale pour la rénovation urbaine: National Agency for urban renovation

Assimilation-intégration: "the concept of 'assimilation' has long been dropped out in French political discourse, if perhaps a touch later than elsewhere, in favor of the concept of 'integration' which leaves the ethical integrity of the individual intact (...). But more importantly, to be French is not defined ethnically or religiously, but politically, in terms of republicanism - France is America's 'sister republic' (Higonnet, 1988) [33].” [3]

Baccalauréat (bac.) : Secondary school leaving examination certificate taken at the end of secondary school, in the final year of "lycée" (terminale), by 17-18 year-olds, after 3 years of studies that begin in the class known as seconde (2nde) and equivalent to the fifth and sixth forms in the British education system. It is not delivered by the school but via a national examination.

Beurs: Immigrants of North African origin living in France.

CODAC: Commissions d'Accès à la Citoyenneté: Commissions of Access to Citizenship.

COPEC: Commission pour la promotion de l'égalité des chances: Commission for the promotion of equal opportunities, ex CODAC.

DEP: Direction de l'Evaluation et de la Prospective. Ministerial assessment and forecasting department, now called

DEPP: Direction de l'évaluation, de la prospective et de la performance. Ministerial assessment, forecasting and performance department.

Dropping in and out: Disaffection can imply complete absence (dropping out) or only partial absence with little participation in class and an extremely passive attitude (dropping in).

ESEN : Ecole supérieure de l'Education Nationale. National School of Higher Education: a school depending on the Ministry of Education and training managers as inspectors and heads of schools.

\section{EU: European Union.}

FAS: Fonds d'action sociale pour les travailleurs immigrés et leur famille: Social action funds for immigrant workers and their families.

HALDE: Haute autorité de lutte contre les discriminations et pour l'égalité: High Authority against discrimination and for equality.

Inclusion: For UNESCO “Inclusion is not about: reforms of special education alone, but reform of both the formal and non-formal education system; responding only to diversity, but also improving the quality of education for all learners; special schools but perhaps additional support to students within the regular school system; meeting the needs of children with disabilities only; meeting one child's needs at the expense of another child." (UNESCO, 2008, p. 8) [8].

It is seen as: "a process of addressing and responding to the diversity of needs of all learners through increasing participation in learning, cultures and communities, and reducing exclusion within and from education [...] Inclusion is concerned with providing appropriate responses to the broad spectrum of learning needs in formal and non-formal educational settings " (UNESCO, 2005, p. 13) [7].

Inclusive education: For UNESCO “ Rather than being a marginal issue on how some learners can be integrated in mainstream education, inclusive education is an approach that looks into how to transform education systems and other learning environments in order to respond to the diversity of learners. It aims towards enabling teachers and learners both to feel comfortable with diversity and to see it as a challenge and enrichment of the learning environment, rather than a problem" (UNESCO, 2005, p. 15) [7].

Laïcité: secularity. For Christian Joppke, it is a variant of American liberalism and France is "America's sister republic", because "As Rawls reminds us in the opening pages of his Political Liberalism, the historical origin of liberalism is in privatisation of religion, which in France is referred to a laïcité (Joppke, 2009, p. 29) [3].

LCO: Langues et Cultures d'Origine: Languages and cultures of origin. Classes were pupils are taught their own culture in their mother tongue.

MGIS: Mission générale d'insertion sociale: General social integration mission.

PRISME: Promotion des Initiatives Sociales en Milieux Educatifs: Fostering Social Initiatives in Education circles.

Tiers état: the lower social class, below the aristocracy and the clergy (Catholic Church). It claimed the right to get equal citizenship in the age of the French Revolution.

UNESCO: United Nations Educational, Scientific and Cultural Organization. 
ZEP: Zone d'éducation prioritaire. Education Priority Zone or area targeted for special help in education $=$ EAZ: Education Action Zones in the UK.

\section{ABOUT THE AUTHOR}

Having a degree in Economy and Finance from Paris IEP (Institute of Political Sciences), Danielle Zay began working in business. Then with an agrégation of Philosophy, the higher level competitive examination for recruiting teachers in France, and a $\mathrm{PhD}$ in Educational sciences, she chose higher education. She specialized in international supported projects for the European Commission, ERDF (European Regional Development Fund), OECD and universities as well as for French ministries, mainly on teacher education and cross-institutional partnerships to deal with youth at risk. She has published numerous articles and books, and has edited a number of special issues in referred journals and reviews, in French, English, Spanish, Galician and Portuguese.

\section{REFERENCES}

[1] Zay D. Preventing school and social exclusion. A French-British comparative study. In: Zay D, Ed. Young people rights and social exclusion EERJ (Eur Educ Res J) 2005.

[2] Zay D. European paradigms of social exclusion and its prevention school models in France and England. In: Zay D, ed. Preventing school and social exclusion of young people. Franco-British approach. Paris: PUF 2005 [In French].

[3] Joppke C. Veil: mirror of identity. Cambridge (UK), Malden (USA): Polity Press 2009.

[4] Lesnes C. French Muslims are more tolerant than their European neighbors. Le Monde 2006 August 29 [In French].

[5] Zay D. Inclusion and education in European countries. Final report: 4. France. Lepelstraat: DOCA Bureaus 2009 August.

[6] Muskens G. Inclusion and education, INTMEAS Interim report for contract -2007-2094/001 TRA-TRSPO. General Overview, Further Steps. Lepelstraat: DOCA Bureaus 2008.

[7] Guidelines for inclusion: ensuring access to education for all. Paris: UNESCO 2005 .

[8] Inclusive education: The way of the future. Geneva; 25-28 November 2008. 48th session of the International Conference on Education; 25-28 November 2008; Geneva: UNESCO.

[9] Carra C. Responses to violence : disparities in professional practice and differentiated effects. The case of French primary schools. In: Zay D, ed. Inclusion and education in European countries final report: 4 France, Lepelstraat: DOCA Bureaus 2009 August.

[10] Lemoine M, Guigue M, Tillard B. "Démission impossible" (impossible resignation): a scheme designed for pupils in difficulty to support the work conducted by professionals. In: Zay D, ed. Inclusion and education in European countries final report: 4 France, Lepelstraat: DOCA Bureaus; 2009 August.

[11] Padoani David G. The democratisation of access to selective education in French higher education : PSE (Projet soutien à l'excellence/excellence support project). In: Zay D, ed. Inclusion and education in European countries final report: 4 France Lepelstraat: DOCA Bureaus 2009 August.

[12] Reuter Y. The fight against school failure in education action networks (REP). In: Zay D, ed. Inclusion and education in
European countries final report: 4 France. Lepelstraat: DOCA Bureaus; 2009 August.

[13] Schnapper D. The universal Republican revisited. The Republican universal testing discrimination, racialization, segregation, VEI Enjeux. 2000 No. 121 (June 2000): 10-21 [In French].

[14] Schnapper D. The community of citizens. On the modern idea of the nation. Paris: Gallimard 1994 [In French].

[15] Maalouf A. Deadly identies. first ed. 1998; Paris: Grasset 2004 [In French].

[16] Maalouf A. Disruption of the world. When our civilization run out. Paris: Grasset, 2009 [In French].

[17] Lorcerie F. The fight against discrimination or integration reclassified. In: The Republican universal testing discrimination, racialization, segregation VEI enjeux $2000 \mathrm{~N}^{\circ} 121$ [In French].

[18] Lorcerie $F$. When Islam claims to secularism and religion. VEI Diversité. 2005, No. 142 (September 2005): 57-68 [In French].

[19] Vallet A, Caille J-P. Foreign or migrant background students in French primary and secondary school. Les Dossiers d'éducation et Formations. 1996, No. 67 [In French].

[20] Laronche M. School failure as trompe l'oeil of the children of immigrants. Le Monde, 2005 July 6 [In French].

[21] Kessous M. The integration of the French of North African origin. The 'beur' elite weaves its own network. Le Monde 2005 December 17 [In French].

[22] Lorcerie F. Intercultural education: current status. In School and cultures, VEI Enjeux 2002 No. 129 (June 2002):170-89 [In French].

[23] Rawls J. Political Liberalism. New York: Columbia University Press 1993.

[24] Lorcerie F. The school and the ethnic challenge: education and integration. Issy-les-Moulineaux, Saint-Fons: Social Actions/Confrontations 2003 [In French].

[25] Bronner L. The state does not keep its promise to renovate the suburbs. Le Monde 2008 November 13 [In French].

[26] Noël O. Balancing between the republican model and the liberal model. Intervention to the symposium CASADIS, CGT, Montreuil, November 8, 2006, The Newsletter of the IRDSU [Interprofessional networks for Urban Social Development), No. 20, December 12, 2008 [In French].

[27] Noël, O. (2010). Sociology of and in the struggle against the discriminations : in the heart of public action in France (19912006). Sarrebruk : Editions universitaires européennes.

[28] Zay D. Inclusive education can it be based on cooperative school model including "community development" ? ECER 09; 27-30 September Vienna 2009.

[29] Zay D. Cooperative school model to promote intercultural dialogue between citizens-to-be. Policy Futures in Education, vol. $9 \mathrm{n}^{\circ} 1$ 2011: 96-103. ERIC n ${ }^{\circ}$ EJ918301.

[30] Zay D. New Educational policies for developing regional partnerships in Europe : analyses and case studies. In: Zay D, ed. Educational partnerships: European case studies and international framework international journal on educational policy, research and practice. San Francisco: Caddo Gap Press 2002: 5-26.

[31] Reuter Y. Freinet schools, functions and effects of an alternative pedagogy among ordinary people. Paris: L'Harmattan 2007 [In French].

[32] Boal A. Theatre of the Oppressed: PCM 1980 [In French].

[33] Higonnet PLR. Sister Republics: The origins of French and American republicanism. Cambridge, Mass.: Harvard University Press 1988.

This is an open access article licensed under the terms of the Creative Commons Attribution Non-Commercial License (http://creativecommons.org/licenses/by$\mathrm{nc} / 3.0 /$ ) which permits unrestricted, non-commercial use, distribution and reproduction in any medium, provided the work is properly cited. 